Стовба Тетяна Анатоліївна кандидат економічних наук, доцент кафедри економіки та морського права, Херсонська державна морська академія, пр. Ушакова, 20, м. Херсон, 73000, тел.: (0552) 49-59-02, e-mail: stovba.t1210@gmail.com, https://orcid.org/0000-0003-2433-1122

\title{
МЕТОДИЧНІ АСПЕКТИ ОЦІНКИ ТА ФОРМУВАННЯ ІННОВАЦЙНОГО ПОТЕНЦІАЛУ МОРСЬКОГО ПОРТУ
}

Анотація. Портова галузь здатна відігравати важливу роль у зростанні української економіки. Інноваційний розвиток морських портів України забезпечить зростання якості життя громадян, скоротить відставання від розвинутих країн світу, дозволить уникнути інформаційної та економічної ізоляції від світової економіки та світового співтовариства, забезпечить розвиток процесів міжнародної інтеграції та ін.

3 метою забезпечення ефективності функціонування i зміцнення конкурентоспроможності на ринку однією з першочергових задач керівництва стає оцінка та формування інноваційного потенціалу морського порту. Інноваційний потенціал визначає можливість економічної системи щодо генерації результатів, які становлять вихідну характеристику інноваційної системи і мають значущість для конкурентоспроможності морського порту.

Запропоновано виділяти у структурі загального потенціалу підприємства портової галузі такі складові: фінансовий потенціал, клієнтський потенціал, потенціал внутрішніх бізнес-процесів, потенціал навчання і розвитку персоналу, а їх оболонкою слугуватиме інноваційний потенціал.

Розроблено методику інтегральної оцінки інноваційного потенціалу морського порту, що враховує як складові інноваційного потенціалу підприємства, так і можливості розвитку галузі у певному регіоні.

Формування потенціалу морського порту - це пошук сукупності характеристик, показників і властивостей, що дозволяють у достатній мірі описати виробничу систему й оцінити іiі можливості щодо забезпечення відповідної суспільної потреби у послугах на перспективу i можливості досягнення поставлених цілей. На підставі розробленої методики інтегральної оцінки інноваційного потенціалу порту, підприємство здатне діагностувати власний інноваційний потенціал. У разі незадоволеності існуючим рівнем для переходу на вищий щабель показники вищого стану слугуватимуть підприємству портової галузі в якості стратегічних цілей, яких слід досягнути.

Ключові слова: морський порт, інноваційний розвиток, інноваційний потенціал морського порту, оцінка інноваційного потенціалу морського порту, формування інноваційного потенціалу морського порту. 
Stovba Tetyana Anatoliyivna Candidate of Economic Sciences, associate professor of Economics and Maritime Law Department, Kherson State Maritime Academy, Ushakov Avenue, 20, Kherson, 73000, tel.: (0552) 49-59-02 e-mail: stovba.t1210@gmail.com, https://orcid.org/0000-0003-2433-1122

\section{METHODOLOGICAL ASPECTS OF EVALUATION AND FORMATION OF SEAPORT INNOVATIVE POTENTIAL}

Abstract. The port industry plays an important role in the growth of the Ukrainian economy. Innovative development of Ukrainian seaports will increase the quality of citizens' life, reduce the gap with developed countries, avoid information and economic isolation from the world economy and the world community and ensure the development of international integration processes and others.

In order to ensure the efficiency of functioning and strengthening of competitiveness in the market, one of the priority tasks of the management is to assess and formation the seaport innovative potential. Innovation potential determines the ability of the economic system to generate results that are the initial characteristics of the innovation system and are important for the competitiveness of the seaport.

It is proposed to allocate the following components in the structure of the general potential of the port industry: financial potential, customer potential, potential of internal business processes, potential of training and development of personnel, and their shell will be innovative potential.

A method of integrated assessment of the innovation potential of the seaport has been developed, which takes into account both the components of the innovation potential of the enterprise and the opportunities for the development of the industry in a particular region.

Formation of seaport innovative potential is a search for a set of characteristics, indicators and properties that allow sufficiently describing the production system and assessing its ability to meet the relevant public need for services in the future and the ability to achieve goals. Based on the developed methodology of integrated assessment of the seaport innovation potential, the company is able to diagnose its own innovation potential. In case of dissatisfaction with the existing level for the transition to a higher level, the indicators of higher status will serve the port industry as a strategic goal to be achieved.

Keywords: seaport, innovative development, innovative potential of the seaport, evaluation of the innovative potential of the seaport, formation of the seaport innovative potential.

Постановка проблеми. Портова галузь України налічує 18 морських портів [1], з яких 13 розташовані на підконтрольній частині (БілгородДністровський, Бердянський, Ізмаїльський, Маріупольський, Миколаївський, Одеський, Ольвія, Південний, Ренійський, Скадовський, Усть-Дунайський, Херсонський, Чорноморський) та 5 - на тимчасово непідконтрольній частині держави (Севастопольський, Євпаторійський, Феодосійський, Ялтинський, Керченський), які мають протяжність причального фронту майже 40 км, а 
довжина підхідних каналів яких становить майже 125 км, що є потужним стимулом для активного розвитку морської транспортної системи.

Вітчизняна морська транспортна система, спираючись на вдале геостратегічне розташування України - на шляхах міжнародних транспортних коридорів, має значний потенціал для розвитку транспортних маршрутів та вантажопотоку. Проте портова галузь не спроможна забезпечити збільшення обсягів вантажообігу через велику кількість проблем, що негативно позначаються на конкурентоспроможності морської інфраструктури.

Основними проблемами українських морських портів $є$ зношеність основних засобів, відсутність глибоководних підходів та якірних місць, застарілі технології обробки суден, неузгодженість розвитку перевантажувальних потужностей та припортових автомобільних та залізничних під’їних шляхів, низький рівень використання електронних систем для оформлення вантажів/суден та технологій взаємодії з контролюючими органами, неефективність митно-тарифної політики, втрата транзитних вантажопотоків, невідповідність портових потужностей структурі сучасних вантажопотоків, відсутність гарантії збереження вантажів та їх своєчасної переробки, відсутність компетентностей щодо можливостей розвитку морських портів [1].

Конкурентоспроможність сучасних морських портів визначається низкою чинників: розташуванням порту щодо основних морських шляхів, свободою виходу на океанські комунікації, відсутністю на морських шляхах до порту ділянок зі складним трафіком; глибинами біля причалів порту, а також глибинами і габаритами підхідних каналів, котрі визначають лінійні розміри суден, що заходять у порт i, отже, розмір суднової партії, яка може бути сформована для відправки через даний порт; довжиною та кількістю причальної лінії, їх адаптованістю для обробки певних типів суден i вантажів; вантажопідйомністю і продуктивністю обладнання порту; швидкістю виконання технологічних, комерційних та адміністративних операцій у порту; існуючими складськими потужностями та наявністю резервних територій для розвитку порту; пропускною здатністю існуючих транспортних комунікацій, порту та хінтерланду; кількістю та якістю регулярних судноплавних ліній та потенціалом інтермодальних перевезень до пунктів хінтерланду; ціною та комплексом основних і додаткових послуг порту; рівнем інформаційного забезпечення порту тощо [1].

У глобальній економіці аби залишатися конкурентоспроможним підприємство має бути інноваційним лідером у технологічній сфері. У світовій економіці фінансування корпораціями наукових розробок зростає, бо віддача багаторазово перевищує інвестиції в основний капітал та фінансові інвестиції. Сільченкова О. наводить такі пропорції розвинутих країн: «якщо на фундаментальні наукові дослідження виділяється певна сума, то на науковотехнологічні розроблення, спрямовані на використання отриманого наукового знання, потрібно передбачити у 2-2,5 рази, а на виробничі інновації - у 10 разів більші кошти. Зате в кінцевому результаті реалізація інноваційної продукції може дати прибуток, який, принаймні, вдесятеро перевищить суму витрат на науку, розроблення та інновації разом узяті» [2, с.5]. 
Інноваційний розвиток вітчизняних морських портів, які у перспективі можуть стати полюсами економічного відродження України, забезпечить зростання якості життя громадян, скоротить відставання від розвинутих країн світу, забезпечить розвиток процесів міжнародної інтеграції.

Тому оцінка існуючого стану й формування потужного інноваційного потенціалу морських портів $\epsilon$ однією із першочергових задач керівництва, вирішення якої сприятиме їх ефективному функціонуванню i зміцненню конкурентоспроможності на міжнародному ринку.

Аналіз останніх досліджень та публікацій. Різні підходи щодо оцінки рівня потенціалу підприємства розкриті у роботах В. Верби, А. Воронкової, А. Гриньова, С. Ілляшенка, І. Новікової, О. Олексюк, І. Рєпіної, О. Федоніна, Н. Чухрай та ін., але існуючі методики не враховують особливостей розвитку портової галузі, що водночас викликає необхідність адаптації вітчизняних оціночних критеріїв до міжнародних стандартів.

Метою статті $є$ розробка методичних положень щодо інтегральної оцінки інноваційного потенціалу морського порту, яка враховуватиме як критерії, необхідні для реалізації стратегії інноваційного розвитку, так і можливості розвитку галузі у певному регіоні, що дозволить встановити індикатори бажаного стану та спрямовуватиме зусилля на їх досягнення.

Виклад основного матеріалу. Розвиток вітчизняних морських портів має відбуватись на інноваційних засадах. Тому особливої уваги в умовах глобальної економіки потребує саме інноваційний потенціал, який характеризує можливості підприємства у сфері розробки та впровадження інновацій.

Слід відзначити, що серед фахівців відсутнє єдине уявлення щодо місця інноваційного потенціалу в структурі загального потенціалу підприємства. Одні автори вважають, що інноваційний потенціал підприємства (ІПП) займає рівнозначну позицію серед різновидів, інші стверджують, що інноваційний потенціал є серцевиною загального потенціалу підприємства. Приєднуємось до думки, що інноваційний потенціал є оболонкою складових загального потенціалу підприємства, який визначає реальну потенційну можливість економічної системи щодо генерування конкурентоспроможних результатів.

Оскільки реалізацію стратегії інноваційного розвитку доцільно здійснювати за допомогою збалансованої системи показників Р. Каплана і Д. Нортона [3, 4], тому вважаємо за доцільне у структурі загального потенціалу підприємства також виокремити відповідно фінансовий потенціал, клієнтський потенціал, потенціал внутрішніх бізнес-процесів, потенціал навчання і розвитку персоналу, де оболонкою слугуватимуть інновації. Тобто інновації мають пронизувати усі складові загального потенціалу підприємства портової галузі.

Аналізуючи зміст окремих елементів ІПП можна зробити висновок про те, що процес інноваційної діяльності розвивається за складною траєкторією i динамікою при одночасному впливі на нього всієї сукупності складових загального потенціалу підприємства.

На підставі проведеного аналізу пропонуємо у загальному вигляді ІПП представити функціональною залежністю: 


$$
\mathrm{IPp}=\mathrm{f}\left(\mathrm{R}_{\phi}, \mathrm{R}_{\mathrm{\kappa}}, \mathrm{R}_{\text {вбп, }} \mathrm{R}_{\text {нр }}\right) \text {, }
$$

де IPp - інноваційний потенціал морського порту;

$\mathrm{R}_{\phi}-$ фінансовий потенціал порту;

$\mathrm{R}_{\mathrm{K}}$ - клієнтський потенціал порту;

$\mathrm{R}_{\text {вбп }}$ - потенціал внутрішніх бізнес-процесів;

$\mathrm{R}_{\text {нр }}$ - потенціал навчання і розвитку персоналу підприємства портової галузі.

У процесі оцінювання ІПП достатньо важливим завданням $\epsilon$ визначення системи показників та їх граничних меж. Наявність нормативів полегшує процес оцінювання ІПП і водночас, у разі незадоволеності існуючою оцінкою, слугує орієнтирами для поліпшення існуючого стану.

Турбулентність економічного оточення унеможливлює встановлення конкретних значень для оцінки поточної ситуації, адже вони можуть не відповідати дійсності та надавати застарілу інформацію. Тому для оцінювання ІПП нормативні значення індикаторів варто розробляти на основі загальнонаціональних тенденцій розвитку портової галузі та статистичних даних, які на даному етапі розвитку економіки України можуть використовуватись переважно в якості граничних критеріїв кризового стану.

Запропонована методика оцінювання ІПП містить мінімальний та, на нашу думку, оптимальний набір показників, які $є$ універсальними для всіх морських портів. Внаслідок того, що окремі підприємства портової галузі мають індивідуальні бачення, місію та стратегічні цілі для більш грунтовного аналізу можливо адаптувати методику, конкретизувавши запропоновані показники шляхом встановлення додаткових індикаторів, які враховуватимуть можливості розвитку галузі у певному регіоні.

Показники відбирались шляхом експертного опитування, де експертам пропонувалось оцінити вагомість впливу кожної складової ІПП - фінансового потенціалу, клієнтського потенціалу, потенціалу внутрішніх бізнес-процесів, потенціалу навчання і розвитку персоналу та визначити перелік показників, які варто діагностувати. Інтервали оцінювання визначено на основі наступних міркувань. Окремі показники мають межі відповідно до загальновизнаних критеріїв економічного та фінансового аналізу. Водночас, деякі показники загалом не мають визначених обмежень, оскільки для кожного порту можуть бути встановлені індивідуальні значення індикаторів, а також, складно передбачити, яким чином вони змінюватимуться внаслідок дії певних заходів.

У таблиці 1 представлена запропонована методика інтегральної оцінки інноваційного потенціалу морського порту.

Таблиияя 1

Методика інтегральної оцінки інноваційного потенціалу морського порту

\begin{tabular}{|c|c|c|c|c|c|}
\hline \multirow{3}{*}{ 导 } & \multirow{2}{*}{ Індикатори } & \multicolumn{4}{|c|}{ Інноваційний потенціал морського порту } \\
\hline & & Високий & Середній & Низький & Відсутній \\
\hline & Оичінка, балів & 4 & 3 & 2 & 1 \\
\hline & 2 & 3 & 4 & 5 & 6 \\
\hline 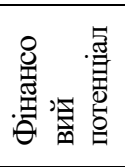 & $\begin{array}{l}\text { Інвестиційна } \\
\text { привабливість регіону }\end{array}$ & $\begin{array}{l}\text { Висока, } \\
\text { відбувається } \\
\text { швидке зростання } \\
\text { інвестицій }\end{array}$ & $\begin{array}{l}\text { Помірна, } 3 \\
\text { середніми темпами } \\
\text { зростання } \\
\text { інвестицій }\end{array}$ & $\begin{array}{l}\text { Нижча за } \\
\text { середню, темпи } \\
\text { зростання нижчі } \\
\text { за середні }\end{array}$ & $\begin{array}{l}\text { Негативна, } \\
\text { зменшення } \\
\text { інвестицій в } \\
\text { економікурегіону }\end{array}$ \\
\hline
\end{tabular}


ISSN (print) 2708-7530

Наукові перспективи № 7(13) 2021

\begin{tabular}{|c|c|c|c|c|c|}
\hline & $\begin{array}{l}\text { Інвестиційна } \\
\text { привабливість порту }\end{array}$ & Висока & Помірна & $\begin{array}{l}\text { Нижча за } \\
\text { середню }\end{array}$ & Негативна \\
\hline & Доступність кредитів & Висока & Помірна & $\begin{array}{l}\text { Нижча за } \\
\text { середню }\end{array}$ & Відсутня \\
\hline & Репутація порту & $\begin{array}{l}\text { Дуже гарна } \\
\text { репутація }\end{array}$ & Гарна репутація & $\begin{array}{l}\text { Репутація } \\
\text { незначна }\end{array}$ & $\begin{array}{l}\text { Негативна } \\
\text { репутація }\end{array}$ \\
\hline & $\begin{array}{l}\text { Темпи приросту прибутку, } \\
\text { \% }\end{array}$ & $>50$ & $11-49$ & $<10$ & - \\
\hline & $\begin{array}{l}\text { Коефіцієнт } \\
\text { незалежності }\end{array}$ & $>0,6$ & $0,41-0,59$ & $0,35-0,4$ & $<0,35$ \\
\hline & $\begin{array}{l}\text { Коефіцієнт забезпеченості } \\
\text { обіговими коштами }\end{array}$ & $>0,5$ & $0,2-0,5$ & $0,1-0,2$ & $<0,1$ \\
\hline & $\begin{array}{l}\text { Прибутковість інновацій, } \\
\%\end{array}$ & $>5,0$ & $2,0-5,0$ & $<2,0$ & - \\
\hline \multirow{5}{*}{ 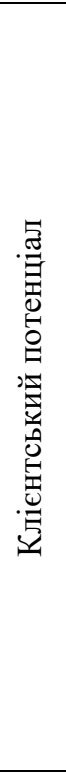 } & $\begin{array}{l}\text { Ступінь задоволення } \\
\text { якістю отриманих } \\
\text { портових послуг }\end{array}$ & $>90$ & $31-89$ & $11-30$ & $<10$ \\
\hline & $\begin{array}{l}\text { Чутливість судноплавних } \\
\text { компаній або } \\
\text { судновласників до } \\
\text { процедури оформлення } \\
\text { суден і вантажів, митно- } \\
\text { тарифної політики, } \\
\text { прикордонного контролю }\end{array}$ & Висока & Середня & $\begin{array}{l}\text { Нижча за } \\
\text { середню }\end{array}$ & - \\
\hline & $\begin{array}{l}\text { Чутливість судноплавних } \\
\text { компаній до інновацій }\end{array}$ & Дуже чутливі & Помірно чутливі & $\begin{array}{l}\text { Нижча за } \\
\text { середню }\end{array}$ & $\begin{array}{l}\text { Не } \\
\text { сприймають } \\
\text { інновації } \\
\end{array}$ \\
\hline & $\begin{array}{l}\text { Розвиненість служби } \\
\text { маркетингу }\end{array}$ & $\begin{array}{l}\text { Розвинута та } \\
\text { спеціалізована } \\
\text { служба }\end{array}$ & $\begin{array}{l}\text { Відсутня } \\
\text { спеціалізація } \\
\text { маркетологів } \\
\end{array}$ & $\begin{array}{l}\text { Кілька } \\
\text { універсальних } \\
\text { маркетологів } \\
\end{array}$ & $\begin{array}{l}\text { Відсутній } \\
\text { відділ } \\
\text { маркетингу }\end{array}$ \\
\hline & $\begin{array}{l}\text { Здатність персоналу } \\
\text { формувати потенційний } \\
\text { попит }\end{array}$ & Висока & Середня & $\begin{array}{l}\text { Нижча за } \\
\text { середню }\end{array}$ & - \\
\hline \multirow{4}{*}{ 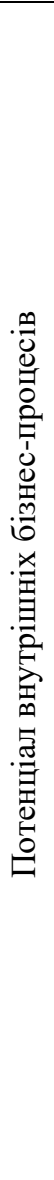 } & $\begin{array}{l}\text { Можливість розвитку } \\
\text { порту (технології обробки } \\
\text { суден, відповідність } \\
\text { портових потужностей } \\
\text { структурі сучасних } \\
\text { вантажопотоків, гарантії } \\
\text { збереження вантажів та їх } \\
\text { своєчасної переробки, сухі } \\
\text { порти) }\end{array}$ & $\begin{array}{l}\text { Висока, } \\
\text { підприємство } \\
\text { здатне швидко } \\
\text { перейти на } \\
\text { надання нових } \\
\text { послуг та } \\
\text { забезпечити їх } \\
\text { якість у заданий } \\
\text { термін }\end{array}$ & $\begin{array}{l}\text { Помірна, порт } \\
\text { здатний } \\
\text { забезпечити } \\
\text { надання послуг } \\
\text { та їх якість у } \\
\text { заданий термін }\end{array}$ & $\begin{array}{l}\text { Низька, порт } \\
\text { здатний } \\
\text { забезпечити } \\
\text { надання } \\
\text { мінімальної } \\
\text { кількості послуг у } \\
\text { заданий термін } \\
\text { при попередній } \\
\text { домовленості }\end{array}$ & $\begin{array}{l}\text { Порт не } \\
\text { здатний } \\
\text { швидко } \\
\text { забезпечити } \\
\text { надання } \\
\text { потрібних } \\
\text { послуг у } \\
\text { заданий } \\
\text { термін }\end{array}$ \\
\hline & $\begin{array}{l}\text { Термін експлуатації } \\
\text { устаткування порту, років }\end{array}$ & $<5$ & $6-10$ & $11-15$ & $>16$ \\
\hline & $\begin{array}{l}\text { Впровадження концепції } \\
\text { смарт-порт (новітніх } \\
\text { технологій, що сприяють } \\
\text { автоматизації та } \\
\text { роботизації } \\
\text { перевантажувальних } \\
\text { процесів морських } \\
\text { терміналів), \% }\end{array}$ & $>50$ & $11-49$ & $<10$ & - \\
\hline & 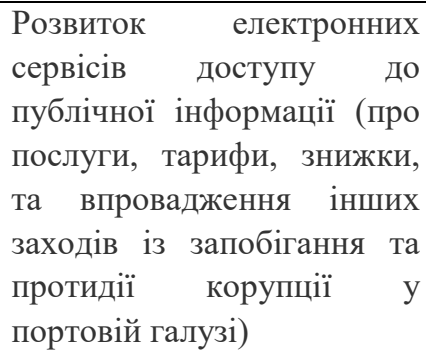 & Високий & Середній & $\begin{array}{l}\text { Нижчий за } \\
\text { середній }\end{array}$ & - \\
\hline
\end{tabular}




\begin{tabular}{|c|c|c|c|c|c|}
\hline & $\begin{array}{l}\text { Впровадження заходів } 3 \\
\text { ресурсозбереження та } \\
\text { раціонального споживання } \\
\text { ресурсів (концепція } \\
\text { «енергоефективний порт»), } \\
\text { використання екологічно } \\
\text { безпечних технологій, } \\
\text { спрямованих на } \\
\text { зменшення шкідливих } \\
\text { викидів від виробничих } \\
\text { процесів у порту, } \\
\text { отримання енергії з } \\
\text { альтернативних джерел } \\
\text { (концепція «зелений } \\
\text { порт»),\% }\end{array}$ & $>10$ & $5-10$ & $<5$ & - \\
\hline & $\begin{array}{l}\text { Рівень використання } \\
\text { принципів та механізмів } \\
\text { корпоративного } \\
\text { управління }\end{array}$ & Високий & Середній & $\begin{array}{l}\text { Нижчий за } \\
\text { середній }\end{array}$ & - \\
\hline 党 & $\begin{array}{l}\text { Здатність персоналу до } \\
\text { генерування нових ідей }\end{array}$ & Висока & Середня & Низька & - \\
\hline 忩 & $\begin{array}{l}\text { Здатність маркетологів } \\
\text { формувати нові потреби }\end{array}$ & $\begin{array}{l}\text { Маркетологи } \\
\text { здатні формувати } \\
\text { нові потреби }\end{array}$ & $\begin{array}{l}\text { Маркетологи } \\
\text { здатні } \\
\text { прогнозувати } \\
\text { попит } \\
\end{array}$ & $\begin{array}{l}\text { Маркетологи } \\
\text { пропонують ідеї } \\
\text { такі, як у лідера }\end{array}$ & $\begin{array}{l}\text { Здатність } \\
\text { відсутня }\end{array}$ \\
\hline 党 & $\begin{array}{l}\text { Здатність керівників } \\
\text { формувати додаткові } \\
\text { інвестиційні ресурси }\end{array}$ & Висока & Середня & Низька & \\
\hline . & $\begin{array}{l}\text { Реалізація програм з } \\
\text { підвищення кваліфікації та } \\
\text { перепідготовки кадрів }\end{array}$ & $\begin{array}{l}\text { Підвищення та } \\
\text { перепідготовка } \\
\text { стосується всього } \\
\text { персоналу }\end{array}$ & $\begin{array}{l}\text { Підвищення та } \\
\text { перепідготовка } \\
\text { стосується } \\
\text { керівників та } \\
\text { спеціалістів } \\
\end{array}$ & $\begin{array}{l}\text { Підвищення та } \\
\text { перепідготовка } \\
\text { стосується лише } \\
\text { керівного } \\
\text { персоналу }\end{array}$ & Відсутня \\
\hline . & $\begin{array}{l}\text { Посилення зовнішньої та } \\
\text { внутрішньої гнучкості } \\
\text { кадрів }\end{array}$ & $\begin{array}{l}\text { Розроблена та } \\
\text { реалізується } \\
\text { програма заходів }\end{array}$ & $\begin{array}{l}\text { Заходи } \\
\text { стосуються } \\
\text { лише } \\
\text { внутрішньої } \\
\text { гнучкості кадрів }\end{array}$ & $\begin{array}{l}\text { Ніяких заходів } \\
\text { щодо посилення } \\
\text { не передбачено }\end{array}$ & \\
\hline
\end{tabular}

Для розрахунку інтегральної оцінки ІПП визначимо бали за кожним із запропонованих показників. При цьому високий рівень ІПП пропонуємо оцінювати у 4 бали, середній - у 3 бали, низький - у 2 бали, відсутність інноваційного потенціалу за деякими показниками оцінюється у 1 бал або 0 балів у разі, якщо індикатор позначений прочерком. Таким чином, за набраною сумою балів можна зробити висновок про ІПП:

76-100 балів - високий інноваційний потенціал, завдяки використанню якого спостерігається якісне та кількісне покращення показників в усіх сферах, порт є лідером на ринку, активно займається соціальною сферою, покращує фінансові показники шляхом задоволення потреб найвимогливіших судновласників.

51-75 - середній рівень ІПП. Тут, переважно, спостерігаються позитивні результати діяльності, деякі показники сягають високого рівня, ефективність діяльності вища за середню у портовій галузі.

16-50 - низький рівень інноваційного потенціалу. Показники діяльності підприємства $є$ нижчими за середньогалузеві, у більшості випадків відбувається 
погіршення показників. Порт перебуває у загрозливому фінансовому становищі $\mathrm{i}$ потребує рішучих управлінських дій.

0-15 - відсутній інноваційний потенціал. Порт майже не володіє власними фінансовими ресурсами, обсяги випуску продукції не відповідають потужностям, майже за всіма показниками спостерігається негативна динаміка.

Для порту, початкові характеристики якого знаходяться на низькому рівні, досягнення показників найвищого рівня може стати важким завданням, яке передбачає визначення пріоритетів у досягненні цілей. Тому адаптуємо запропоновану інтегральну оцінку інноваційного потенціалу шляхом впровадження коефіцієнтів вагомості експертним методом для кожної складової потенціалу, які розподілилися наступним чином (таблиця 2). Але, як зазначено вище, у кожному регіоні вагомість потенціалів може відрізнятися, що необхідно враховувати під час оцінювання.

Таблиия 2

Вагомість складових інноваційного потенціалу морського порту

\begin{tabular}{|l|c|}
\hline \multicolumn{1}{|c|}{ Потенціал } & Вагомість \\
\hline Фінансовий потенціал & 0,27 \\
\hline Клієнтський потенціал & 0,31 \\
\hline Потенціал внутрішніх бізнес-процесів & 0,19 \\
\hline Потенціал навчання і розвитку персоналу & 0,23 \\
\hline
\end{tabular}

Таким чином, інтегральну оцінку інноваційного потенціалу морського порту можна визначити наступним чином:

$$
\begin{gathered}
\text { ІОІПП }=I_{\phi n}+I_{к n}+I_{в б n}+I_{n n}, \\
I_{\phi n}=K_{i} * \sum C_{i}, \quad I_{к n}=K_{j} * \sum C_{j}, \quad I_{в б n}=K_{f} * \sum C_{f}, \quad I_{n n}=K_{l} * \sum C_{l},
\end{gathered}
$$

де

$I_{\phi n}, I_{k n}, I_{в б n,} I_{n n}$ - індикатори здатності до інновацій фінансового, клієнтського, потенціалу внутрішніх бізнес-процесів i навчання та розвитку персоналу відповідно;

$C_{i}, \quad C_{j}, \quad C_{f}, C_{l}$ - кількість балів відповідно фінансового, клієнтського потенціалу, потенціалу внутрішніх бізнес-процесів та навчання i розвитку персоналу;

$K_{i}, \quad K_{j}, \quad K_{f}, \quad K_{l}$ - коефіцієнти вагомості, які були присвоєні експертами фінансовому, клієнтському потенціалу, потенціалу внутрішніх бізнес-процесів $\mathrm{i}$ потенціалу з навчання та розвитку персоналу (таблиця 2) [5].

В результаті підстановки значень підприємства у таблиці 1 та проведення необхідних розрахунків, з'ясовується рівень ІПП (таблиця 3). 


\section{Інтервальні оцінки рівнів ІПП}

\begin{tabular}{|c|c|}
\hline Рівень ІПП & Інтервальні оцінки \\
\hline Високий & $17,14-24,00$ \\
\hline Середній & $10,27-17,13$ \\
\hline Низький & $3,40-10,26$ \\
\hline Відсутній & до 3,39 \\
\hline
\end{tabular}

Для апробації запропонованої методики здійснимо оцінку ІПП для державного підприємства «Херсонський морський торговельний порт» (таблиця 4) [6].

Таблиия 4

\section{Приклад інтегральної оцінки інноваційного потенціалу ДП «Херсонський морський торговельний порт»}

\begin{tabular}{|c|c|}
\hline Складові & $\begin{array}{l}\text { Оцінка, } \\
\text { бали }\end{array}$ \\
\hline \multicolumn{2}{|l|}{ Фінансовий потенціал } \\
\hline Інвестиційна привабливість регіону & 2 \\
\hline Інвестиційна привабливість порту & 2 \\
\hline Доступність кредитів & 1 \\
\hline Репутація порту & 2 \\
\hline Темпи росту прибутку, \% & 2 \\
\hline Коефіцієнт фінансової незалежності & 2 \\
\hline Коефіцієнт забезпеченості обіговими коштами & 2 \\
\hline Прибутковість інновацій, \% & 1 \\
\hline Разом & 14 \\
\hline \multicolumn{2}{|l|}{ Кліснтський потенціал } \\
\hline Ступінь задоволення якістю отриманих портових послуг & 2 \\
\hline $\begin{array}{l}\text { Чутливість судноплавних компаній або судновласників до процедури оформлення } \\
\text { суден і вантажів, митно-тарифної політики, прикордонного контролю }\end{array}$ & 4 \\
\hline Чутливість судноплавних компаній до інновацій & 4 \\
\hline Розвиненість служби маркетингу & 1 \\
\hline Здатність персоналу формувати потенційний попит & 0 \\
\hline Разом & 11 \\
\hline \multicolumn{2}{|l|}{ Потенціал внутрішніх бізнес-процесів } \\
\hline $\begin{array}{l}\text { Можливість розвитку порту (технології обробки суден, відповідність портових } \\
\text { потужностей структурі сучасних вантажопотоків, гарантії збереження вантажів та } \\
\text { їх своєчасної переробки, сухі порти) }\end{array}$ & 2 \\
\hline Термін експлуатації устаткування порту, років & 1 \\
\hline $\begin{array}{l}\text { Впровадження концепції смарт-порт (новітніх технологій, що сприяють автоматизації } \\
\text { та роботизації перевантажувальних процесів морських терміналів), \% }\end{array}$ & 0 \\
\hline $\begin{array}{l}\text { Розвиток електронних сервісів доступу до публічної інформації (про послуги, } \\
\text { тарифи, знижки, та впровадження інших заходів із запобігання та протидії корупції } \\
\text { у портовій галузі) }\end{array}$ & 2 \\
\hline
\end{tabular}




\begin{tabular}{|l|c|}
\hline $\begin{array}{l}\text { Впровадження заходів з ресурсозбереження та раціонального споживання ресурсів } \\
\text { (концепція «енергоефективний порт»), використання екологічно безпечних } \\
\text { технологій, спрямованих на зменшення шкідливих викидів від виробничих процесів у } \\
\text { порту, отримання енергії з альтернативних джерел (концепція «зелений порт»), }\end{array}$ & 0 \\
\hline Рівень використання принципів та механізмів корпоративного управління & 2 \\
\hline Разом & 7 \\
\hline Потенціал навчання і розвитку персоналу порту & 1 \\
\hline Здатність персоналу до генерування нових ідей & 1 \\
\hline Здатність маркетологів формувати нові потреби & 2 \\
\hline Здатність керівників формувати додаткові інвестиційні ресурси & 2 \\
\hline Реалізація програм з підвищення кваліфікації та перепідготовки кадрів & 1 \\
\hline Посилення зовнішньої та внутрішньої гнучкості кадрів & 7 \\
\hline Разом & 10,13 \\
\hline ІОІПП & \\
\hline
\end{tabular}

Отже, ДП “ХМТП» має низький рівень інноваційного потенціалу. У разі досягнення ним граничного рівня, відмови у процесі аналізу від коефіцієнтів вагомості, вдосконалення інноваційного потенціалу виражатиметься у якісному покращенні індикаторів, що передбачає необхідність їх вивчення у динаміці.

Потенціал підприємства не $\epsilon$ його іманентною властивістю і залежить від дії i впливу макро- i мікросередовища. Тому виникає необхідність у формуванні потенціалу морського порту.

Формування потенціалу порту $\epsilon$ складним динамічним процесом, орієнтованим на максимальну взаємодію із зовнішнім середовищем i забезпечення високої якості реалізації його стратегії розвитку, на яке впливає багато факторів, що обумовлюють розвиток його елементів і впливають на їхню збалансованість та ефективність використання.

3 рис. 1 витікає, що для управління інноваційним розвитком порту слід спиратись на бачення, місію країни, цілі держави та регіону, адже ринкове середовище, в якому відбувається його функціонування, невпинно змінюється: зростає ступінь його невизначеності, виникають невраховані чинники ризику. 


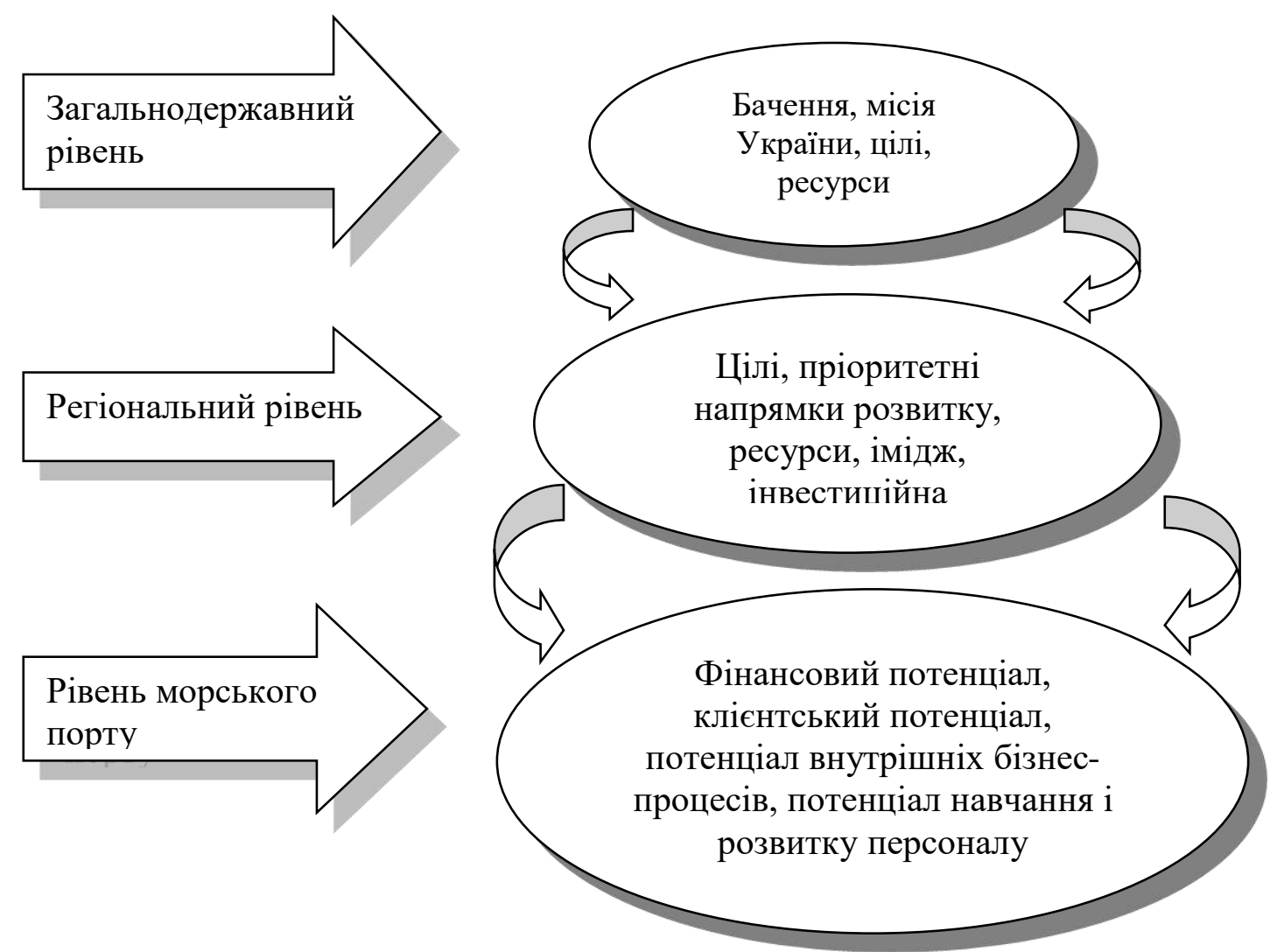

Pис. 1. Модель формування потениіалу підприємства

Джерело: Розроблено автором

Найбільш складною проблемою, що виникає при визначенні системи регіону як об'єкта стратегічного управління, $є$ проблема виявлення елементів i можливостей системи, сукупність і взаємодія яких створюють об'єктивні передумови для встановлення цілей і вибору найбільш раціональної стратегії їх досягнення, тобто оцінка його потенціалу 3 урахуванням зовнішнього середовища.

Отже, враховувати необхідно не тільки ресурсний потенціал системи регіону і виробничі потужності, але й конкурентоспроможність на внутрішньому й зовнішньому ринку, кліматичні умови, географічне розташування, природні ресурси, розвиненість інфраструктури, інноваційні можливості, інвестиційну привабливість, фінансову стійкість, репутацію, здатність до адаптації й самоорганізації та ряд інших інформаційних характеристик зовнішнього й внутрішнього середовища.

Висновки. Розроблена методика інтегральної оцінки інноваційного потенціалу морського порту враховує наступні складові - фінансовий потенціал, клієнтський потенціал, потенціал внутрішніх бізнес-процесів, потенціал навчання і розвитку персоналу та можливості розвитку портової галузі у певному регіоні. Відтак на підставі розробленої методики інтегральної оцінки ІПП, морський порт здатний діагностувати власний інноваційний потенціал. У разі незадоволеності існуючим рівнем для переходу на вищий щабель показники вищого стану слугуватимуть підприємству портової галузі в якості стратегічних цілей, яких слід досягти. 
Формування потенціалу передбачає реалізацію низки заходів щодо забезпечення ринкових можливостей порту шляхом зміни його характеристик $\mathrm{i}$ властивостей до необхідного рівня відповідно до поставлених стратегічних цілей.

\section{Лimepamypa:}

1. Стратегія розвитку морських портів України на період до 2038 року : Розпорядження Кабінету Міністрів України від 23 грудня 2020 p. № 1634-p. URL: https://zakon.rada.gov.ua/laws/show/548-2013-\%D1\%80\#n11/ (дата звернення 10.07.2021).

2. Сільченкова О.С Інтелектуальний потенціал України: як ми його використовуємо? Науковий світ. 2006. № 8. С. 4-6.

3. Каплан Р.С., Нортон Д.П. Организация, ориентированная на стратегию. Как в новой бизнес-среде преуспевают организации, применяющие сбалансированную систему показателей. Москва : ЗАО «Олимп - Бизнес», 2004. 416 с.

4. Каплан Р.С., Нортон Д.П. Стратегические карты. Трансформация нематериальных активов в материальные результаты. Москва : ЗАО «Олимп-Бизнес», 2005. 483 с.

5. Стовба Т.А. Системне відродження підприємств легкої промисловості на інноваційних засадах: монографія. Херсон : Айлант, 2010. 296 с.

6. Сайт державного підприємства «Херсонський морський торговельний порт». URL: https://seaport.kherson.ua/ru/vidkriti-danni/bezgotivkovi-rozrahunki-statistika/ (дата звернення 10.07.2021).

\section{References:}

1. Stratehiya rozvytku mors'kykh portiv Ukrayiny na period do 2038 roku : Rozporyadzhennya Kabinetu Ministriv Ukrayiny [Strategy for the development of seaports of Ukraine for the period up to 2038: Order of the Cabinet of Ukraine Ministers]. (n.d.). zakon.rada.gov.ua. Retried from https://zakon.rada.gov.ua/laws/show/548-2013-\%D1\%80\#n11/ [in Ukrainian].

2. Sil'chenkova, O.S. (2006). Intelektual'nyy potentsial Ukrayiny: yak my yoho vykorystovuyemo? [Intellectual potential of Ukraine: how do we use it?] Naukovyy svit - Scientific world, 8, 4-6 [in Ukrainian].

3. Kaplan, R.S., \& Norton, D.P. (2004). Organizatsiya, oriyentirovannaya na strategiyu. Kak v novoy biznes-srede preuspevayut organizatsii, primenyayushchiye sbalansirovannuyu sistemu pokazateley. [Strategy-oriented organization. How organizations with a balanced scorecard thrive in the new business environment] Moskva: ZAO «Olimp - Biznes» [in Russian].

4. Kaplan, R.S., \& Norton, D.P. (2005).Strategicheskiye karty. Transformatsiya nematerial'nykh aktivov $v$ material'nyye rezul'taty [Strategic cards. Transformation of intangible assets into tangible results]. Moskva: ZAO «Olimp-Biznes» [in Russian].

5. Stovba, T.A. (2010) Systemne vidrodzhennya pidpryyemstv lehkoyi promyslovosti na innovatsiynykh zasadakh [System revival of light industry enterprises on innovative principles]. Kherson: Aylant [in Ukrainian].

6. Sait derzhavnoho pidpryyemstva «Khersons'kyy mors'kyy torhovel'nyy port» [Site of the state enterprise "Kherson sea trade port"]. https://seaport.kherson.ua. Retried from https://seaport.kherson.ua/ru/vidkriti-danni/bezgotivkovi-rozrahunki-statistika/ [in Ukrainian]. 